\title{
Ampulla of Vater Cancer pNX TNM Finding v7
}

National Cancer Institute

\section{Source}

National Cancer Institute. Ampulla of Vater Cancer pNX TNM Finding v7. NCI Thesaurus. Code C90275.

Ampulla of Vater cancer in which the regional lymph nodes cannot be assessed. (from AJCC 7th Ed.) 